\title{
MULTIPLE-SCALE DYNAMIC LEACHING OF A MUNICIPAL SOLID WASTE INCINERATION ASH
}

\section{Waste Management (in press)}

D. Guyonnet ${ }^{1 *}$, F. Bodénan ${ }^{1}$, G. Brons-Laot ${ }^{2}$, A. Burnol ${ }^{1}$, L. Chateau ${ }^{3}$, M. Crest ${ }^{4}$, J. Méhu $^{2}$, P. Moszkowicz $^{4}$, P. Piantone ${ }^{1}$

${ }^{1}$ BRGM, BP 6009, 3 av. C. Guillemin, 45060 Orléans Cedex

${ }^{2}$ POLDEN, BP 2132, 69603 Villeurbanne Cedex Lyon, France.

${ }^{3}$ ADEME, 2 square La Fayette, BP 90406, 49004 Angers

${ }^{4}$ LAEPSI, 20 av. A. Einstein, 69621 Villeurbanne Cedex.

* corresponding author: Tel : (33) 238643817 -d.guyonnet@brgm.fr

\begin{abstract}
:
Predicting the impact on the subsurface and groundwater, of a pollutant source such as municipal solid waste (MSW) incineration ash, requires a knowledge of the so-called "source term". The source term describes the manner in which concentrations in dissolved elements in water percolating through waste evolve over time, for a given percolation scenario (infiltration rate, waste source dimensions, etc.). If the source term is known, it can be coupled with a model that simulates the fate and transport of dissolved constituents in the environment of the waste (in particular in groundwater), in order to calculate potential exposures or impacts. The standardized laboratory upward-flow percolation test is generally considered as a relevant test for helping to define the source term for granular waste. The LIMULE project (Multiple-Scale Leaching) examined to what extent this test, performed in very specific conditions, could help predict the behaviour of waste at other scales and for other conditions of percolation. Three distinct scales of percolation were tested: a laboratory upward-flow percolation column $(30 \mathrm{~cm})$, lysimeter cells $(1-2 \mathrm{~m})$ and a large column $(5 \mathrm{~m})$ instrumented at different depths. Comparison between concentration data collected from the different experiments suggests that for some non-reactive constituents $(\mathrm{Cl}, \mathrm{Na}, \mathrm{K}$, etc), the liquid versus solid ratio $(\mathrm{L} / \mathrm{S})$ provides a reasonable means of extrapolating from one scale to another: if concentration data are plotted versus this ratio, the curves coincide quite well. On the other hand, for reactive elements such as chromium and aluminium, which are linked by redox reactions, the L/S ratio does not provide a means of extrapolation, due in particular to kinetic control on reactions. Hence extrapolation with the help of coupled chemistry-transport modelling is proposed.
\end{abstract}

Key words: Leaching, Waste, Incineration ash, Chromium, L/S ratio, Modelling. 


\section{Introduction}

The acceptability of different methods of waste management (for example landfilling of incineration residues versus utilization as secondary materials) depends in part on predictions of potential environmental impacts. Impact predictions are often performed using models that simulate the fate and transport of pollutants in various environmental compartments (water, air, soil). With respect to the subsurface and groundwater, predicting potential impacts requires knowledge of the so-called "source term" (see CEN, 2006a). This source term describes, for a given waste and a specific scenario, for instance a percolation scenario, the manner in which pollutant emission varies as a function of time. If this source term is known, it can be coupled with a model that calculates pollutant fate and transport in the unsaturated zone underlying the waste or in the groundwater. But risk assessments for soil and groundwater often rely on simplifying assumptions regarding pollutant concentrations in the water emitted by the source (the waste) and in particular the assumption of constant concentrations, with values selected based on solubility limits. Such an assumption neglects in particular both the transient character of pollutant release from waste and also the finite character of available pollutant mass. In order to address the source term, various laboratory tests have been defined. While static batch tests (CEN, 2002, 2006b), whereby the source (the waste) is mixed with the solvent (water) at a specific liquid/solid ratio, provide information regarding the cumulative mass of pollutant that can be mobilized, dynamic percolation tests are considered to be more representative of source term behaviour for granular inorganic waste (see van der Sloot et al., 1997, Fällman and Aurell, 1996, Wahlström, 1996). The standardized upward-flow percolation test (CEN, 2005) consists schematically in flowing water in the upward direction through a $30 \mathrm{~cm}$-height column at a certain rate and monitoring pollutant concentrations at the column outlet. The question then arises as to how representative are the results of this test with respect to source term behaviour at other scales and for other percolation conditions? In other words, how can the upward-flow column test help us to estimate the leaching behaviour of the waste for the problem at hand?

The influence of scale has been studied by previous authors. Van der Sloot et al. (2001) compared leaching data from tests performed on a mixture of different waste residues at the laboratory scale, the scale of lysimeter experiments and a pilot test scale. They observed similarities in the leaching experiment data with differences originating from different redox conditions. Kylefors et al. (2003) studied the leaching of MSW at different scales and found 
that the tests were not reliable for predicting the liquid/solid (L/S) ratio required to reach a certain concentration. They suggest that predictions would require better knowledge regarding leaching mechanisms. This paper presents results of the LIMULE project (Guyonnet et al., $2005 \mathrm{a} ; 2005 \mathrm{~b}$ ) that examined the influence of scale and percolation conditions on the mobilization of soluble constituents from a municipal solid waste (MSW) incineration ash. The focus of this paper is on the possible use of the L/S ratio as a means of extrapolating between scales and percolation conditions.

\section{Materials and methods}

The waste studied within the LIMULE project is a boiler ash from a fluidized-bed MSW incineration plant. This ash was selected primarily due to its particle size which is close to that of a sand. In order to limit the potential for material setting that might decrease the hydraulic conductivity and hence the ability to reach a significant value of L/S over the duration of the experiments, the ash was mixed in equal weight proportions with clean Loire river silica sand (0.1-1 mm), with a fraction $<80 \mu \mathrm{m}$ lower than $1 \%$ in weight. Thirty tons of the ash-sand mixture were produced using a horizontal rotating mixing tube.

The ash-sand mixture underwent detailed characterization with respect to physical properties influencing leaching behaviour and chemical properties. Procedures used to sample the initial ash-sand mixture and the final leached solid are described in Guyonnet et al. (2005a). Chemical analysis of the solid included X-ray fluorescence (Philips PW2400; sequential) for the determination of major elements, ICP-AES spectroscopy for trace elements (and major elements in the leached samples), potentiometry for chloride and atomic absorption spectrometry (following extraction in a methanol bromine solution) for metallic aluminium $\left(\mathrm{Al}^{0}\right)$. Concentrations of $\mathrm{Cr}(\mathrm{VI})$ in the solid were determined colorimetrically (with the 1,5diphenylcarbonhydrazide method) after a hot alkaline extraction. It should be noted however (Abbas et al. 2001), that in the presence of reducing agents such as $\mathrm{Al}^{0}$, this method may lead to a systematic underestimation of $\mathrm{Cr}(\mathrm{VI})$ concentrations in the solid. The same problem occurs when $\mathrm{Cr}(\mathrm{VI})$ is measured following $24 \mathrm{~h}$ batch leaching tests. The quantification of $\mathrm{Cr}(\mathrm{VI})$ in the solid in presence of reducing agents is a particularly difficult task and the subject of ongoing research. 
A micro-characterization of fresh samples and polished thin sections was performed using a powder X-ray diffractometer (Siemens D5000, cobalt $\mathrm{K}_{\alpha 1}$ radiation), an optical microscope, a scanning electron microscope (SEM) coupled with energy dispersive spectrometry (EDS) and an electronic microprobe coupled with wavelength dispersive spectrometry (WDS) for multielement micro-mapping and quantitative analyses. Standard procedures were followed for the chemical analysis of the waters collected from the leaching experiments (see below). Samples were filtrated at $0.45 \mu \mathrm{m}$ and sub-samples for cation analyses were acidified. Dissolved concentrations (including $\mathrm{Cr}_{\text {total }}$ ) were determined by ICP-AES with a sequential Jobin Yvon JY 38 device (NF EN ISO 11885 standard) and Ionic Chromatography (for $\mathrm{Cl}$ and $\mathrm{SO}_{4}$; $\mathrm{NF}$ EN ISO 10304 standard). Hexavalent chromium in the liquid was analysed by colorimetry. Results showed that $\mathrm{Cr}$ in the water samples was present exclusively as $\mathrm{Cr}(\mathrm{VI})$ and therefore ICP results on $\mathrm{Cr}_{\text {total }}$ were taken as $\mathrm{Cr}(\mathrm{VI})$ concentrations because of the lower quantification limit ( $5 \mu \mathrm{g} / \mathrm{l}$ for the ICP-AES as compared to $10 \mu \mathrm{g} / \mathrm{l}$ for the colorimetric method). Additional details of analytical methods and results will be provided in an independent paper (in preparation) focused on the chemistry of the ash.

Standard batch tests were performed at a liquid/solid (L/S) ratio of 10: the leaching test for granular waste (CEN, 2002) and the pH-dependence leaching test (CEN, 2006b). Upward flow laboratory column tests were performed according to standard CEN (2005). Two pilotscale downward-flow percolation experiments were performed in lysimeter cells fed with demineralised water. One cell (2.5 m long, $1.75 \mathrm{~m}$ wide and $1 \mathrm{~m}$ high) was located indoors and equipped with a device for controlling infiltration (Fig. 1), while the other cell $(2.5 \mathrm{~m}$ wide, $2.5 \mathrm{~m}$ large and $2 \mathrm{~m}$ high) was located outdoors and exposed to natural rainfall. A downward-flow percolation experiment was performed in a large column fed with demineralised water (Fig. 1). Thirty litres per day were sprayed with sprinklers at the top of the column by means of 10 litres every 8 hours. The column is 5 metres high and 1 metre in diameter and is made up of 5 superposed cylinders equipped with ports for the monitoring of temperature, water content (TDR probes), capillary pressure (tensiometer probes) and fluid composition (porous cups). Concentrations in fluids collected from 5 porous cups (noted PC1 through PC5) located at different depths within the column, as well as at the column outlet, were monitored over time. Tracer tests were performed in the lysimeter cells and the large column in order to obtain information regarding hydrodynamic parameters (effective porosities and dispersivities). Table 1 summarizes the main characteristics of the various experiments conducted under conditions of dynamic flow. The table illustrates the contrast of 
scales and infiltration rates between the experiments. A primary constraint regarding the choice of experimental conditions for the large column and indoor lysimeter experiments, was the need to reach a value of L/S ratio over the duration of the project (19 months of experimental monitoring) that allowed results to be compared with the laboratory column data, while avoiding infiltration rates that were several orders of magnitude larger than those encountered in natural field conditions. A compromise value of $\mathrm{L} / \mathrm{S}=3$ was selected as a minimum objective.

\section{Results}

\subsection{Physical and chemical characterization}

Average particle density of the ash-sand mixture from pycnometry is $2.64 \mathrm{~g} . \mathrm{cm}^{-3}$, i.e. a value close to the density of silica sand $\left(2.68 \mathrm{~g} . \mathrm{cm}^{-3}\right)$. Apparent dry density measured as the average of ten sub-samples is $1.32 \mathrm{~g} . \mathrm{cm}^{-3}$ while BET surface area is $2.61 \mathrm{~m}^{2} \cdot \mathrm{g}^{-1}$. Particle size analysis of the fresh ash, before mixture with the Loire river sand, shows that particle size is lower than $500 \mu \mathrm{m}$ with a fine fraction $(<63 \mu \mathrm{m})$ representing $9 \%$ in weight. A bulk measure of dry density was obtained from the measurement of the total mass installed in the large column: $5285 \mathrm{~kg}$ in a volume of $3.79 \mathrm{~m}^{3}$, yielding a dry density of $1.39 \mathrm{~g} \mathrm{~cm}^{-3}$. Considering the particle density, the void ratio is 0.47 . This void ratio was not saturated during the large column and lysimeter cell experiments. In Fig. 2a, the volumetric water content measured at a depth of $294 \mathrm{~cm}$ in the large column by a TDR probe shows a very stable value around $30 \%$. This value, which was observed in all the TDR probes except the uppermost (closest to the sprinklers) can be compared to the value of $47 \%$ at saturation. The uppermost probe, located at $20.5 \mathrm{~cm}$ from the top, indicated an average water content of $23 \%$ and showed small fluctuations related to the cyclic water feed (every 8 hours). Overall steady-state flow conditions are illustrated by plots of cumulative inflow and outflow that are seen in Fig. $2 b$ to be very linear. A slight difference between the inflow (30.1 1/day) and outflow (28.3 1/day) slopes is interpreted as being due primarily to evaporation at the top of the column (calculated as $2.4 \mathrm{~mm} /$ day from the difference in slopes)

Major elements in the ash-sand mixture are related to the presence of Si-rich oxidized phases and to a lesser extent to the presence of $\mathrm{Al}, \mathrm{Ca}, \mathrm{Fe}$ and $\mathrm{K}$ (see Table 2). Trace elements in the ash-sand mixture are, by order of decreasing importance, $\mathrm{Zn}, \mathrm{Cu}, \mathrm{Ba}, \mathrm{Pb}, \mathrm{Sn}, \mathrm{Sr}$. The proportion of zero-valent (metal) aluminium found in two analyses is 1.4 and $1.45 \%$. As will 
be shown below, this zero-valent aluminium has a major influence on the behaviour of chromium. From XRD analysis, the ash contains primarily quartz, silicates such as microcline, plagioclase, diopside, gehlenite, carbonates such as calcite, some sulphates (anhydrite) and iron oxides (hematite). Amorphous phases are also present and calcium phosphates were identified by microscopic analyses.

A characterisation of the waste after 580 days of leaching in the large column (average of 5 analyses; Table 2) shows a decrease in the proportion of metal aluminium: on average, $60 \%$ of metal aluminium has been altered. This result is consistent with SEM observations that show an alteration of aluminium particles. For other elements, comparison of the global analyses of the solid before and after leaching show differences that are not significant except for $\mathrm{SiO}_{2}$, although this is most probably due to the difference in analytical methods: unlike $\mathrm{X}$ ray fluorescence, ICP-AES is not an adequate technique for precisely measuring $\mathrm{SiO}_{2}$ at such a high content (60-80\%; C. Crouzet, pers. comm.).

Scanning Electron Microscopy observations show the precipitation of aluminium hydroxides and the alteration of quartz and feldspath grains (development of micro-fissures). There is also formation of hydrated phases such as ettringite $\left(\mathrm{Ca}_{6} \mathrm{Al}_{2}\left(\mathrm{SO}_{4}\right)_{3} \cdot 26 \mathrm{H}_{2} \mathrm{O}\right)$ which, with the aluminium hydroxides $\left(\mathrm{Al}(\mathrm{OH})_{3}\right)$, help explain swelling that was observed in the lysimeter cells. Some degree of swelling occurred and resulted in some deformation of the lysimeters. However, it was not possible to detect a significant effect on the material's void ratio. No swelling was detected during the large column experiment, although some may have occurred as suggested by temperature variations measured during the first twenty days of leaching in the large column (Fig. 2c).

Leaching tests performed at $\mathrm{L} / \mathrm{S}=10(\mathrm{CEN}, 2002)$ on the fresh ash-sand mixture show a $\mathrm{pH}$ of 10.3 (Table 3). The leachate contains primarily $\mathrm{Ca}, \mathrm{Na}, \mathrm{K}, \mathrm{Cl}, \mathrm{SO}_{4}$, and $\mathrm{Al}$ as well as traces of $\mathrm{Ba}, \mathrm{Cr}(\mathrm{VI})$ and Sr. A leaching test was also performed on the waste sampled from the large column after the leaching experiment and dried at $105^{\circ} \mathrm{C}$. As could be expected, proportions of $\mathrm{Na}, \mathrm{Cl}, \mathrm{K}$ and $\mathrm{Ca}$ are lower than prior to leaching (Table 3). Hexavalent chromium concentrations appear higher at the end of the experiment which suggests some oxidation of $\mathrm{Cr}(\mathrm{III})$ to $\mathrm{Cr}(\mathrm{VI})$ during the experiment, in accordance with the observed trend towards more oxidizing conditions (Fig. 3b; Brookins, 1988). It is reminded, however, that in the presence of $\mathrm{Al}^{0}, \mathrm{Cr}(\mathrm{VI})$ concentrations tend to be underestimated. Results of leaching tests are 
compared in Table 3, for reference, to the landfill waste acceptance criteria (OJC, 2002). The ash-sand mixture complies with the non-hazardous waste criteria and following the leaching experiment, it also complies with inert waste criteria for all parameters except for chromium which is close to the limit.

\subsection{Results of dynamic leaching tests as a function of $\mathrm{L} / \mathrm{S}$ ratio}

In this section, concentration data collected from the various dynamic leaching tests are plotted as a function of L/S ratio and compared. Note that for a constant infiltration rate, the L/S ratio can be written (see Hjelmar et al., 2003):

$$
L / S=\frac{I t}{d h}
$$

where: $I=$ constant infiltration rate, $t=$ time, $d=$ waste density, $h=$ height of the waste column.

This simple equation has been used by previous authors to provide a means of extrapolation from one percolation scenario to another. The concentration versus L/S ratio measured for a certain scenario (in particular the laboratory column test) is used as a type-curve and the concentration versus time relationships for other scenarios are calculated by setting $I, d$ and $h$ in Eq.(1) accordingly.

Figure 3 compares the evolution of $\mathrm{pH}$, Eh and electrical conductivity (Eh measurements are available for the large column experiment only). The $\mathrm{pH}$ is slightly higher in the large column $(11.5$ - 12) than in the laboratory column (11) while the values from the indoor cell appear to fluctuate. As shown in Fig. 3b, the redox potential (Eh) at the outlet of the large column increased gradually from values lower than $0 \mathrm{mV}$ to values above $100 \mathrm{mV}$ at the end of the experiment. Figure 4 shows non-reactive (or poorly reactive) soluble constituent $(\mathrm{Cl}, \mathrm{Na}, \mathrm{K}$, $\mathrm{Ca}$ ) concentrations, as a function of L/S ratio (based on collected outflow volumes). The curves show a typical decreasing shape and a relatively good correspondence between experiments (except for $\mathrm{Na}$ lab-column data). The characteristic shape of the curves suggests that these constituents are rapidly dissolved and then gradually diluted by incoming demineralised water. The plots for $\mathrm{Na}$ and $\mathrm{K}$ display "bumps" that are remarkably consistent between the indoor cell and the large column. These bumps, observed at the same values of 
$\mathrm{L} / \mathrm{S}$, are interpreted as the effect of an ion-exchange mechanism: it is well known (Drever, 1988) that from thermodynamic considerations the dilution of a solution enhances the adsorption of divalent cations (such as $\mathrm{Ca}$ ) to the expense of monovalent cations (such as $\mathrm{Na}$ and K). It is unsure however which surface is responsible for the adsorption (possibly ettringite). Figure 5 compares results for non-reactive constituents, including data from the outdoor lysimeter, over a limiting L/S window. Data are seen to coincide reasonably well.

Figure 6 compares the evolutions of concentrations for reactive constituents. In particular for chromium, there is not a good correspondence between data from different experiments. Notice the inverse correlation between aluminium and chromium: chromium appears when aluminium decreases. The same trends were observed in the data from all five porous cups of the large column (see Guyonnet et al., 2005b) and suggests the simultaneous oxidation of metal aluminium $\left(\mathrm{Al}^{0}\right)$ to $\mathrm{Al}(\mathrm{III})$ with a reduction of $\mathrm{Cr}(\mathrm{VI})$ to $\mathrm{Cr}(\mathrm{III})$. So long as there is $\mathrm{Al}^{0}$ to oxidize, chromium is in its less mobile trivalent form. These results are consistent with those of Chen et al. (2003) and Astrup et al. (2006) who performed batch tests on incineration residues and showed the oxidation of $\mathrm{Al}^{0}$ in presence of $\mathrm{Cr}(\mathrm{VI})$.

Sulphate behaviour also varied with experimental conditions. As shown in Fig. 6a, in the lab column experiment, $\mathrm{SO}_{4}$ decreased with increasing $\mathrm{L} / \mathrm{S}$ ratio, which is consistent with a dissolution of Ca-sulphates. But in the large column and indoor cell, concentrations were found to increase with time (Fig. 6a). This could be explained by a late release of neoformed sulphates that had time to accumulate (Ca-sulphates but also neoformed ettringite). The same type of delayed behaviour was observed during leaching of a bottom ash heap by Freyssinet et al. (2002).

The plots of concentrations as a function of L/S ratio were found to be very useful: for the case of non-reactive constituents, the relatively good correspondence between the data collected during the experiments performed at different scales and using different percolation rates suggests that the L/S ratio might be used as a tool to extrapolate between percolation scenarios. Data from experiments performed by Crest et al. (2005) on the same ash-sand mixture in column tests with alternating flow conditions also suggest a good correspondence for non-reactive constituents. On the other hand, for constituents that are influenced by reactions and reaction kinetics (see next section), the L/S ratio does not provide a means of 
extrapolation. This is observed here for aluminium and especially chromium, elements that are influenced by redox reactions, with specific reaction kinetics.

\section{Modelling results}

Since extrapolation between experiments using the L/S ratio is not satisfactory for the case of reactive constituents such as $\mathrm{Cr}$ and $\mathrm{Al}$, a modelling approach was adopted. In accordance with the principle of parcimony that states that the simpler model explaining observations should be preferred to the more complex model, several models of varying complexities were tested.

\subsection{Exponential decay model}

The exponential decay model is a simple model that is often used for fitting dynamic leaching experiments (see Hjelmar et al., 2001). The conceptual model is that of a continuously stirred and diluted reactor: the model assumes that at time $t=0$, all available mass is instantaneously dissolved (yielding an initial concentration noted $\left\langle C_{\mathrm{o}} »\right)$ and that this concentration is then gradually diluted by incoming water. The exponential decay model is written:

$$
C_{s}=C_{o} \exp (-L S k)
$$

where $k$ is a kinetic parameter which, for a non-reactive constituent, is shown in the appendix to be the waste mass per unit pore volume. If the L/S ratio has units of $1 / \mathrm{kg}$, then the $k$ parameter has units of $\mathrm{kg} / \mathrm{l}$.

An attempt to reproduce concentrations measured at the outlet of the large column is presented in Fig. 7a. The match between measured and calculated concentrations, obtained for a value $k=10 \mathrm{~kg} / \mathrm{l}$ and presented in cartesian scale, might appear satisfactory, but a plot in semi-logarithmic scale (Fig. 7b) shows that the measured data display a curvature that an exponential model cannot, by definition, reproduce.

\subsection{CSTR cascade model}

A continuously-stirred tank reactor (CSTR) cascade model (Tiruta-Barna et al., 2000), with exchanges between mobile and immobile porosities, was used to reproduce the behaviour of 
non-reactive constituents $(\mathrm{Na}, \mathrm{K}, \mathrm{Cl})$. Primary model fitting-parameters are the number of reactors (noted $n$; which controls dispersion), the proportion of mobile versus total porosity (noted $a$ ) and the rate coefficient controlling exchange between mobile and immobile porosities (noted $b$ ).

Application of the model to the different experiments suggests that inclusion of a double porosity allows the "tails" observed in the non-reactive constituent data to be reproduced. However, it was always necessary to readjust fitting parameters when passing from one scale to another. This is illustrated by Fig. 8 which shows fits to chloride data from the lysimeter cell (Fig. 8a) and from the large column (Fig. 8b). The match to the lysimeter cell data was obtained using: $\mathrm{n}=6, \mathrm{a}_{1}=0.15, \mathrm{a}_{2}=0.05, \mathrm{~b}_{1}=0.7, \mathrm{~b}_{2}=0.0003$, the subscripts indicating that two immobile zone porosities were required to match the data. The match to the large column data was obtained using: $\mathrm{n}=6, \mathrm{a}_{1}=0.048, \mathrm{a}_{2}=0.95, \mathrm{~b}_{1}=0.02, \mathrm{~b}_{2}=0.00003$. While unlike the exponential model, the long "tails" displayed by the measured data can be reproduced in semi-logarithmic scale when multiple porosity is included, the necessity to readjust model fitting parameters when simulating the data from each experiment underlines limits in predictive capability and therefore in the ability to extrapolate between percolation scenarios.

\subsection{Coupled chemistry-transport modelling}

As was shown previously, the L/S ratio did not provide a means of extrapolation in the case of reactive constituents when reaction kinetics influence the behaviour. This was the case for $\mathrm{Al}$ and $\mathrm{Cr}$ that are linked by redox reactions. In order to attempt to reproduce the behaviour of these elements and provide a means of extrapolation, a coupled chemistry-transport model (PHREEQC ; Parkhurst and Appelo, 1999) was used. The model couples dissolved constituent transport by advection and dispersion with chemical speciation reactions. The first step for performing such modelling is the identification of phases controlling solubilities and the selection of adequate thermodynamic data. Gibbsite $\left(\mathrm{Al}(\mathrm{OH})_{3}\right)$ is generally considered to control the solubility of aluminium (Hsu, 1977, Eary, 1999). Comparison between geochemical simulations (Guyonnet et al., 2005a) and aluminium solubility observed in the large column (see Fig. 6b) suggest that the microcrystalline form of Gibbsite (Gibbsite $(\mu \mathrm{c})$ ) is a possible controlling phase. Next, several hypotheses were tested with respect to oxidoreduction of the Al-Cr couple, by confronting model results with the measured data. At the elevated values of $\mathrm{pH}$ observed ( $\mathrm{pH}$ 11.25), it was hypothesized as in Astrup et al (2005), 
that chromium concentrations were the result of the following simultaneous and competitive reactions:

- kinetic dissolution of $\mathrm{Cr}(\mathrm{VI})$ :

$$
\mathrm{Cr}(\mathrm{VI})(\mathrm{s}) \rightarrow \mathrm{Cr}(\mathrm{VI})(\mathrm{aq})
$$

- $\mathrm{Al}^{0}$ oxidation by $\mathrm{Cr}(\mathrm{VI}), \mathrm{O}_{2}$ and/or $\mathrm{H}_{2} \mathrm{O}$ :

$$
\begin{aligned}
& \mathrm{Al}^{0}(\mathrm{~s})+\mathrm{CrO}_{4}{ }^{2-}+4 \mathrm{H}_{2} \mathrm{O} \rightarrow \mathrm{Al}(\mathrm{OH})_{4}{ }^{-}+\mathrm{Cr}(\mathrm{OH})_{3}(\mathrm{~s})+\mathrm{OH}^{-} \\
& \mathrm{Al}^{0}(\mathrm{~s})+0,75 \mathrm{O}_{2}(\mathrm{aq})+1.5 \mathrm{H}_{2} \mathrm{O}+\mathrm{OH}^{-} \rightarrow \mathrm{Al}(\mathrm{OH})_{4}{ }^{-} \\
& \mathrm{Al}^{0}(\mathrm{~s})+\mathrm{OH}^{-}+3 \mathrm{H}_{2} \mathrm{O} \rightarrow \mathrm{Al}(\mathrm{OH})_{4}{ }^{-}+1.5 \mathrm{H}_{2}(\mathrm{aq})
\end{aligned}
$$

where (s) and (aq) indicate solid and aqueous phases.

Oxygen and water were included as oxidants because, from mass balance considerations, experimental data suggest that another oxidant than $\mathrm{Cr}(\mathrm{VI})$ must be involved. If one assumes that $\mathrm{Cr}(\mathrm{VI})$ is the sole oxidant of metal aluminium $\mathrm{Al}^{0}$ (Eq. 4), then the release of one mole of $\mathrm{Al}(\mathrm{III})$ in solution would require the reduction of one mole of $\mathrm{Cr}(\mathrm{VI})$ in solution. But from results in Table 3, the initial quantity of available $\mathrm{Cr}(\mathrm{VI})$ in the ash-sand mixture is estimated to be on the order of $1 \mathrm{mg} / \mathrm{kg}$. This estimate is based on the value of $0.84 \mathrm{mg} / \mathrm{kg}$ measured in the leaching test performed on the waste sampled from the large column (Table 3) after leaching and on the fact that very little $\mathrm{Cr}(\mathrm{VI})$ was exported from the large column during the experiment (only $0.03 \mathrm{mg} / \mathrm{kg}$ ). Considering the volumetric water content of $30 \%$ and the particle density of $2.64 \mathrm{~g} / \mathrm{cm} 3$, the total dissolution of $1 \mathrm{mg} / \mathrm{kg} \mathrm{Cr}(\mathrm{VI})$ would yield a concentration of approximately $10^{-4} \mathrm{~mol} / \mathrm{l}$. But such a concentration cannot account for the maximum $\mathrm{Al}$ concentration observed in the large column (Fig. $6 \mathrm{~b} ; 140 \mathrm{mg} / \mathrm{l}$, i.e., $52 \times 10^{-4}$ mol/l). The model therefore takes explicitly into account the transport of aqueous oxygen (10 $\mathrm{mg} / \mathrm{l}$ in the inflowing water) and the quantity of aqueous oxygen in solution is controlled by the oxidation of reactive Al, following (see also Astrup et al., 2005):

$$
\frac{d\left(A l^{0}{ }_{r}\right)}{d t}=-k_{A l-o x}\left(A l^{0}{ }_{r} / M_{0}\right)^{p}\left[O_{2}(a q)\right]^{q}
$$

with: 


$$
\frac{d(C r(V I)(a q))}{d t}=k_{C r-s}-k_{C r-r e d}[C r(V I)(a q)] A l^{o}{ }_{r}
$$

where: $A l_{\mathrm{r}}^{0}=$ amount of reactive metal aluminium at time $t, M_{0}=$ initial amount of reactive metal aluminium, $k_{A l-o x}=$ kinetic constant for the oxidation of metal aluminium, $k_{C r-s}=$ rate of $\mathrm{Cr}(\mathrm{VI})(\mathrm{s})$ dissolution, $k_{C r-\text { red }}=$ kinetic constant for $\mathrm{Cr}(\mathrm{VI})(\mathrm{aq})$ reduction, $p=$ surface exponent and $q=$ oxygen exponent.

These Stoichiometries of reactions (3) through (6) and kinetic rates were specified in the PHREEQC input file and the advective-dispersive equation was solved using a finite difference algorithm. Discretization was optimized using the Peclet and Courant criteria to minimize numerical dispersion. Figure 9 shows the results of a match to data collected from the large column in porous cups located at two depths (PC3 at $254 \mathrm{~cm}$ and PC4 at $356 \mathrm{~cm}$ ) and using the same values of fitting parameters: $M_{0}=300 \mathrm{mg} / \mathrm{kg}$, initial available $\mathrm{Cr}(\mathrm{VI})$ in the solid $=1 \mathrm{mg} / \mathrm{kg}, k_{\text {Al-ox }}=2 \times 10^{-6} \mathrm{~mol} \mathrm{l}^{-1} \mathrm{~s}^{-1}, k_{C r-s}=10^{-12} \mathrm{~mol} \mathrm{l}^{-1} \mathrm{~s}^{-1}, k_{\text {Cr red }}=4 \times 10^{-4} \mathrm{~mol}$ $1^{-1} s^{-1}, p=2 / 3, q=1 / 2$. It is seen that the overall observed behaviour of aluminium decrease, coinciding with $\mathrm{Cr}(\mathrm{VI})$ increase, is reproduced. Figure 10 shows results of a "blind" simulation of laboratory column data using the same fitting parameters as previously. The overall behaviour is reproduced reasonably well, suggesting that the model may have some potential for scale extrapolation.

Note that the value of reactive metal aluminium $(300 \mathrm{mg} / \mathrm{kg})$ used to fit the measured data is very close to the difference between $\mathrm{Al}$ leached at $\mathrm{L} / \mathrm{S}=10$ before and after the experiment (see Table 3). The rates of aluminium oxidation, chromium reduction and dissolution are fitting parameters that are adjusted during the process of matching measured and calculated $\mathrm{Al}$ and $\mathrm{Cr}$ concentrations. Although there are, to our knowledge, no examples in the literature of such rates for this type of waste material, one can compare the value of aluminium oxidation to the rate of pyrite oxidation observed in batch experiments by Williamson and Rimstidt (1994). These authors measured a rate of $10^{-8.19} \mathrm{~mol} \mathrm{~m}^{-2} \mathrm{~s}^{-1}$ which, considering the surface area of their material $\left(0.051 \mathrm{~m}^{2} \mathrm{~g}^{-1}\right)$ and the liquid-solid ratio $(4 \mathrm{~g} / \mathrm{l})$, yields a value of $10^{-6.3} \mathrm{~mol} \mathrm{l}^{-1} \mathrm{~s}^{-1}$, which is of the same order of magnitude as the value obtained here for aluminium oxidation. 


\section{Discussion and conclusions}

The LIMULE project provided data regarding leaching of a MSW incineration ash mixed with Loire sand, at different scales of observation and for periods up to 19 months. The particular emphasis of this paper is on the ability to extrapolate between scales and conditions of percolation using the $\mathrm{L} / \mathrm{S}$ ratio. It was found that this ratio provided a means of extrapolation for the case of non-reactive constituents such as soluble salts $(\mathrm{Cl}, \mathrm{Na}, \mathrm{K}, \mathrm{Ca})$ : when the concentration data are plotted versus L/S ratio, the curves coincide reasonably well suggesting that one curve can be used as a type-curve to provide a concentration versus time relationship for other percolation scenarios. For reactive constituents on the other hand, the L/S ratio does not provide a means of extrapolation. This was found to be the case for aluminium and chromium, two elements that are linked by redox reactions with specific reaction kinetics: oxidation of metal aluminium and reduction of $\mathrm{Cr}(\mathrm{VI})$ to $\mathrm{Cr}$ (III).

If the evolution of an element in solution is controlled by reaction kinetics rather than by the rate at which water is percolating through the waste, then using the L/S ratio to extrapolate from the small scale to the large scale will have the effect of overestimating times of element breakthrough (unconservative estimates). This is illustrated schematically in Fig. 11 which represents two columns (noted 1 and 2) of different lengths, filled with the same waste and fed with water at the same constant rate. If we measured the evolution of concentrations (noted $\mathrm{C} 1$ and $\mathrm{C} 2$ ) at the column outlets over time, we might obtain the curves depicted in Fig. 11a: column 2 being longer, the element appears later than in column 1, but the delay is not very large because it is a reaction kinetic that is controlling breakthrough (as was the case for $\mathrm{Cr}$; Fig. 6d) rather than the amount of water that has percolated through the column. We now plot the data as a function of L/S ratio rather than time (Fig. 11b). As cumulative volumes are divided by a much smaller mass in the case of column 1 (full line), the curve for column 1 is offset to the right with respect to column 2 (dashed curve). Let us now assume that we have not "measured" the concentration versus time relationship of column 2 in Fig. 11a but wish to "predict" it using the concentration versus L/S of column 1 in Fig. 11b: we obtain the dashed curve in Fig. 11c; times are offset to the right with respect to the "measured" times in Fig. 11a, implying that breakthrough times are overestimated.

Considering that the L/S ratio does not provide a means of extrapolation in the case of reactive elements, it was proposed to extrapolate using modelling. Attempts to fit measured 
data using a simple exponential decay model showed that even for a non-reactive constituent such as chloride, this model fails to reproduce the observed behaviour: when plotted in semilogarithmic scale, the data from the different experiments display a curvature that the exponential model cannot reproduce. With respect to application of this model, it is recommended that it be applied to concentration data (rather than to cumulative emission data) and that the quality of the fit be judged on the basis of a plot in semi-logarithmic rather than in cartesian scale. With respect to predicting non-reactive constituent behaviour for other percolation scenarios, results presented here suggest that rather than fitting the exponential model to measured laboratory data, it would seem preferable to use the measured data, plotted versus L/S, directly as a type curve.

Modelling of non-reactive constituents using a CSTR cascade model with mobile and immobile porosities show that sets of model fitting parameters can generally be found such that measured data are reproduced (in particular the observed curvature in semi-logarithmic scale). However, the modelling also illustrates the difficulty to extrapolate between scales since reproducing the data from each experiment required a new adjustment of model fitting parameters and in particular of the proportions of mobile versus immobile porosities and the constants controlling mass exchange between these porosities.

Difficulty in simulating the behaviour of reactive constituents, such as aluminium and chromium, using a coupled chemistry-transport model, resides primarily in the number of parameters involved: stock of reactive metal aluminium that can be oxidized, availability of oxygen in the system, kinetics of the reactions of $\mathrm{Al}^{0}$ oxidation and $\mathrm{Cr}(\mathrm{VI})$ reduction, choice of mineral phases controlling the solubility of aluminium and chromium, selection of thermodynamic data for theses phases, etc. While the modelling tool was found to be extremely valuable for exploring different hypotheses regarding mechanisms controlling the behaviour of $\mathrm{Al}$ and $\mathrm{Cr}$ in this system, truly predictive capability remains limited due to the complexity involved. However, the predictive capability of such modelling is increasing, provided it relies upon detailed characterization of the waste (see for example Kosson et al., 2002). For example, it was found in this project that reproducing the results of the $\mathrm{pH}$ dependent solubility test (CEN, 2006b) with a geochemical speciation model, could help considerably in guiding choices with respect to the selection of mineral phases to be included in the predictive modelling (Guyonnet et al., 2005a). As the waste is solicited during this test over a large range of $\mathrm{pH}$ values, it yields a global response that provides information 
regarding the mineral assemblage controlling solubilities. By coupling this information with mineralogical observations, the model can be constrained and hence its predictive capability improved.

With respect to the source term, one essential piece of information for predictions of potential impacts is the maximum concentration value in the water emitted from the waste. Table 4 summarizes maximum values of concentration measured during the various dynamic leaching experiments performed in this project, and the L/S ratio at which these maximum concentrations were observed. For soluble salts it is seen, as expected, that the highest concentrations correspond to the lowest values of L/S. For a constituent such as chloride which has an enormous solubility and in spite of the equilibration period included in the standard test (CEN 2005), the first value of concentration measured in the laboratory test (at $\mathrm{L} / \mathrm{S}=0.1$ ) does not provide an adequate estimate of the maximum concentration that can be expected during flow through a larger column of waste, where the first significant values of L/S may be much lower. Taking for example a $20 \mathrm{~m}$ high column of waste with a density of $1500 \mathrm{~kg} / \mathrm{m}^{3}$ and considering a typical value of net infiltration of $300 \mathrm{~mm} / \mathrm{year}$, a $\mathrm{L} / \mathrm{S}$ ratio of 0.1 corresponds (Eq. 1) to 10 years. As shown in this study, chloride concentrations at lower $\mathrm{L} / \mathrm{S}$ ratios and hence smaller times may be significantly higher. As a prospect, it would seem useful to define a procedure that would allow the identification of maximum concentrations that are more representative of potential field conditions. If several points are measured during the laboratory column test at low values of $\mathrm{L} / \mathrm{S}(0.1,0.2,0.3,0.4,0.5)$, it might be possible to identify a meaningful curvature that could help extrapolate to even lower values of L/S (for example 0.01) that cannot easily be reached experimentally.

Considering the complexity of source term behaviour for the case of reactive constituents, the question remains as to the extrapolation of the standardized upward-flow laboratory column test to field conditions. Several options might be considered. Tests could be performed at different rates in laboratory columns of different sizes, thus providing direct information regarding extrapolation. Pilot-scale tests, that are more representative of true field conditions, can be performed, especially if laboratory results indicate that there is an environmental issue. In any case, characterization should be performed in parallel with the modelling effort since the ultimate objective is generally to be able to predict a potential environmental impact; such predictions necessarily rely at some stage on model calculations. 


\section{Acknowledgements}

We thank Pierre Gallé, Marc Gamet (BRGM) and Mohammed Abdelghafour (POLDEN) for their valuable contributions to the LIMULE project, ADEME (the French Agency for Environment and Energy Management) for its financial support, CIDEME for providing the incineration ash and an anonymous reviewer.

\section{References}

Abbas, Z., Steenari, B-M., Lindqvist, O. (2001) - A study of Cr(VI) in ashes from fluidized bed combustion of municipal solid waste: leaching, secondary reactions and the applicability of some speciation methods. Waste Management, 21, 725-739.

Astrup, T., Dijkstra, J., Comans, R., Van der Sloot, H., Christensen, T. (2006) - Geochemical modeling of leaching from MSWI air-pollution-control residues. Environ. Sci. Technol., 40(11), 35513557.

Astrup T., Rosenblad C., Trapp S., Christensen T.H., (2005) - Chromium Release from Waste Incineration Air-Pollution-Control Residues. Environ. Sci. Technol., 39(9), 3321 -3329.

Belevi, H., Baccini, P. (1989) - Long-term behaviour of municipal solid waste landfills. Waste Management \& Research (7): 43-56.

Brookins, D.G. (1988) - Eh-pH diagrams for geochemistry : Springer-Verlag, New York.

CEN (2006a) - EN 12920, Methodology guideline for the determination of the leaching behaviour of waste under specified conditions. European Committee for Standardization, Brussels.

CEN (2006b) - CEN/TS 14429 Characterization of waste - Leaching behaviour tests Influence of $\mathrm{pH}$ on leaching with initial acid/base addition. European Committee for Standardisation, Brussels.

CEN (2005) - CEN/TS 14405. Characterisation of waste - Leaching behaviour tests - Upflow percolation test (under specified conditions). European Committee for Standardisation, Brussels. 
CEN (2002) - EN 12457-2. Characterisation of waste - Leaching - Compliance test for leaching of granular waste materials and sludges. European Committee for Standardisation, Brussels.

Chen D., T. Astrup, C. Rosenblad, T. H. Christensen (2003) - Factors affecting chromium leaching from waste incineration on residues. Proceedings Sardinia 2003, Ninth International Waste Management and Landfill Symposium, Italy.

Crest, M., Blanc, D., Moszkowicz, P., Dujet, C. (2005) - Experimental percolation under intermittent conditions and bases of a fuzzy rule-based model to describe pollutant emission from waste. In: WasteEng-2005, Albi, 17-19 May 2005.

Drever, J. (1988) - The geochemistry of natural waters. Prentice Hall. Englewood Cliffs, NJ, USA, $437 \mathrm{pp}$.

Eary E.D. (1999) - Geochemical and equilibrium trends in mine pit lakes. Applied Geochemistry, 14, 963-987.

Fällman, A.-M., Aurell, B. (1996) - Leaching tests for environmental assessment of inorganic substances in wastes, Sweden. The Science of the Total Environment, 178, 71-84.

Freyssinet, P., Piantone, P., Azaroual, M., Itard, Y., Clozel-Leloup, B., Guyonnet, D., Baubron, J.-C. (2002) - Chemical changes and leachate mass balance of municipal solid waste bottom ash submitted to weathering. Waste Management, 22(2): 159-172.

Guyonnet, D., Bodénan, F., Brons-Laot, G., Burnol, A., Crest, M., Méhu, J., Moszkowicz, P., Piantone, P., Thomassin, J.-F. (2005a) - Projet LIMULE. Comportement à la lixiviation de cendres d'UIOM étudié à plusieurs échelles. Project LIMULE. Leaching behaviour of a MSW incineration ash examined at different scales. Final Report, BRGM/RP 54322 - FR, Orléans, France (in French).

Guyonnet, D., Bodénan, F., Brons-Laot, G., Crest, M., Chateau, L., Méhu, J., Moszkowicz, P., Piantone, P. (2005b) - Pollutant emission from waste : influence of scale and rate of percolation. In: WasteEng-2005, Albi, 17-19 May 2005.

Hjelmar, O., Van der Sloot, H., Guyonnet, D., Rietra, R., Brun, A. Hall, D. (2001) Development of acceptance criteria for landfilling of waste : an approach based on impact modelling and scenario calculations. Proceedings SARDINIA-2001, (Th. Christensen, R. Cossu and R. Stegmann Eds.). S. Margherita di Pula, Cagliari (Italy), Vol. 3, 711-721. 
Hsu, P.H. (1977) - Aluminium hydroxides and oxi-hydroxides. In: Dixon, J.B., Weed, S.B. (Eds.), Minerals in Soil Environments. Soil Sci. Soc. Am., Madison, Wisconsin, 99-143.

Kosson, D., van der Sloot, H., Sanchez, F., Garrabrants, A. (2002) - An integrated framework for evaluating leaching in waste management and utilization of secondary materials. Environmental Engineering Science, Vol. 19, No. 3, 159-203.

Kylefors, K., Andreas, L., Lagerkvist, A. (2003) - A comparison of small-scale, pilot-scale and large-scale tests for predicting leaching behaviour of landfilled wastes. Waste Management, 23, 45-59.

OJC (2002) - Council Decision of 19 December 2002 establishing criteria and procedures for the acceptance of waste at landfills pursuant to Article 16 of Annexe II to Directive 1999/31/EC. Official Journal of the European Communities L 11/27, 16 january 2003.

Parkhurst D.L., Appelo C.A.J. (1999) - User's guide to PHREEQC (version 2) - A computer program for speciation, batch-reaction, one-dimensional transport, and inverse geochemical calculation. U.S. Geological Survey, Water-Resources Investigations. Report 99-4259, $312 \mathrm{pp}$.

Tiruta-Barna, L., Barna, R., Moszkowicz, P., Hae-Ryong, B. (2000) - Distributed mass transfer rate for modelling the leaching of porous granular materials containing soluble pollutants. Chemical Engineering Science, 55, 1257-1267.

Van der Sloot, H.A., Heasman, L., Quevauviller, P. (Eds.), (1997) - Harmonization of leaching/extraction tests. Studies in Environmental Science, Vol 70. Amsterdam: Elsevier Science Publishers.

Van der Sloot, H.A., Van Zomeren, A., Rietra, R.P., Hoede, D., Scharff, H. (2001) Integration of lab-scale testing, lysimeter studies and pîlot scale monitoring of a predominantly inorganic waste landfill to reach sustainable landfill conditions. SARDINIA-2001, (Th. Christensen, R. Cossu and R. Stegmann Eds.). S. Margherita di Pula, Cagliari (Italy), Vol. 1, 254-264.

Wahlström, M. (1996) - Nordic recommendation for leaching tests for granular waste materials. The Science of the Total Environment, 178, 95-102.

Williamson, M.A., Rimstidt, D. (1994) - The kinetics and electrochemical rate-determinig step of aqueous pyrite oxidation. Geochimica et Cosmochimica Acta, 58(24): 5443-5454. 


\section{Appendix: derivation of the exponential decay equation and meaning of the $\boldsymbol{k}$ parameter}

We consider flow at a constant rate $Q$ through a column of volume $V$, height $h$ and section $S$. Waste dry density is $d$, volumetric porosity is $n$ and total available mass of a given constituent is $M_{\mathrm{m}}$. Constituent concentration in inflowing water $\left(C_{\mathrm{in}}\right)$ is zero. At time $\mathrm{t}=0$ it is assumed that all the available mass $M_{\mathrm{m}}$ is instantaneously dissolved, yielding a concentration $C_{\mathrm{o}}$ that is subsequently diluted by inflowing water at zero concentration. It is also assumed perfect mixing throughout the column porosity. We derive expressions for concentration $\left(C_{\text {out }}\right)$ and cumulative emission $\left(E_{\text {out }}\right)$ at the outlet.

Mass flux into the column is: $\quad F_{i n}=Q C_{i n}=0$

Mass flux out of the column is: $\quad F_{\text {out }}=Q C_{\text {out }}$

From mass balance, the difference between the flux in and out of the column is the difference in mass in the column. For a non-reactive constituent:

$$
F_{\text {out }}-F_{\text {in }}=-n V \frac{\partial C_{p}}{\partial t}
$$

where $C_{\mathrm{p}}$ is solute concentration in the column pore water. Since perfect mixing is assumed: $C_{\mathrm{p}}=C_{\text {out }}$, hence:

$$
Q\left(C_{\text {out }}-C_{\text {in }}\right)=-n V \frac{\partial C_{\text {out }}}{\partial t}
$$

Assuming $C_{\mathrm{in}}=0$ and dividing by the column section yields:

$$
\frac{\partial C_{\text {out }}}{\partial t}=-\frac{I}{n h} C_{\text {out }}
$$

where $I$ is infiltration per unit section.

Integrating:

$$
\int \frac{1}{C_{\text {out }}} \partial C=\int-\frac{I}{n h} \partial t
$$

yields:

$$
\left[\ln \left(C_{\text {out }}\right)\right]_{C_{o}}^{C_{\text {out }}}=-\frac{I}{n h} t
$$

hence:

$$
C_{\text {out }}=C_{o} \exp \left(-\frac{I}{n h} t\right)
$$


The initial concentration $C_{\mathrm{o}}$ is the result of the instantaneous dissolution of available mass $M_{\mathrm{m}}$ into pore volume $n V$ :

$$
C_{o}=\frac{M_{\mathrm{m}}}{n V}
$$

Expressing available mass per unit mass of dry waste:

$$
A=\frac{M_{m}}{d V}
$$

where $A$ is dubbed "availability".

yields:

$$
M_{m}=A d V
$$

Substituting into (9):

From (8):

$$
\begin{aligned}
& C_{\mathrm{o}}=\frac{A d V}{n V}=A \frac{d}{n} \\
& C_{\text {out }}=A \frac{d}{n} \exp \left(-\frac{I}{n h} t\right)
\end{aligned}
$$

Cumulative emission $E_{\text {out }}$ per unit mass of dry waste is obtained by integrating the flux out with respect to time:

$$
E_{\text {out }}=\frac{1}{d V} \int Q C_{\text {out }} \partial t
$$

Substituting (13) and simplifying by the section $S$ yields:

$$
\begin{aligned}
& E_{\text {out }}=\frac{1}{d h} \int I A \frac{d}{n} \exp \left(-\frac{I}{n h} t\right) \partial t \\
& E_{\text {out }}=-\frac{I A h n}{h n I} \exp \left(-\frac{I}{n h} t\right)+C n t
\end{aligned}
$$

where $C n t$ is an integration constant.

Simplifying:

$$
E_{\text {out }}=-A \exp \left(-\frac{I}{n h} t\right)+C n t
$$

The integration constant is obtained by setting time to infinity: $C n t=E_{\infty}=A$

Hence:

$$
E_{\text {out }}=A\left(1-\exp \left(-\frac{I}{n h} t\right)\right)
$$


Previous researchers express Equations (8) and (18) as a function of the liquid/solid (L/S) ratio, defined as:

$$
L S=\frac{I t}{d h}
$$

and introduce a parameter $k$ such that:

$$
C_{\text {out }}=C_{o} \exp (-L S k)
$$

and:

$$
E_{\text {out }}=A(1-\exp (-L S k))
$$

Comparing equations (8), (18) and (20), (21) it follows that:

$$
k=\frac{d}{n}
$$

Relationships below, which follow from the above, are also sometimes used:

$$
\begin{aligned}
& C_{o}=A k \\
& E=\frac{C_{o}}{k}(1-\exp (-L S k))
\end{aligned}
$$

Parameter $k$ is therefore the ratio between waste dry density and volumetric porosity (units of $\mathrm{kg} / \mathrm{l})$. It is the waste mass per unit pore volume. It follows that in this model, the rate of concentration decrease is just a function of the flushing rate $(I)$ and the "reactor volume" ( $h$ $n$ ). It is worth noting that Equation (20) is identitical to Equation (7) of Belevi and Baccini (1989) with: $k=c_{\mathrm{o}} / m_{\mathrm{o}}$ in the notation of these authors. Correspondence with the parameter notation herein is: $c_{\mathrm{o}}=C_{\mathrm{o}}$ and $m_{\mathrm{o}}=A$.

Note that for a solute that is assumed to undergo reversible and instantaneous adsorption, with a retardation coefficient $R$, Equations (20) and (21) require that:

$$
k=\frac{d}{R n}
$$

And Equation (12) requires that Equation (23) be written:

$$
C_{o}=A k R
$$


Table 1

Characteristics of the experiments performed under conditions of dynamic flow

\begin{tabular}{lcccc}
\hline \multicolumn{1}{c}{ Scale of experiment } & $\begin{array}{c}\text { Infiltration } \\
(\mathbf{c m} / \text { day })\end{array}$ & $\begin{array}{c}\text { Infiltration } \\
\text { conditions }\end{array}$ & Duration & $\begin{array}{c}\text { L/S } \\
\text { reached }\end{array}$ \\
\hline 1: Upward-flow percolation column $(30 \mathrm{~cm})$ & 15 & Controlled & 60 days & 20 \\
2: Indoor lysimeter cell $(1 \mathrm{~m})$ & 0.55 & Controlled & 590 days & 2.5 \\
2: Outdoor lysimeter cell $(2 \mathrm{~m})$ & 0.11 on average & Uncontrolled & 610 days & 0.3 \\
3: Large column $(5 \mathrm{~m})$ & 3.8 & Controlled & 580 days & $3^{*}$ \\
\hline
\end{tabular}

*: 3 at the outlet, but up to 24 in the uppermost porous cup 
Table 2

Global chemical composition of the fresh ash-sand mixture (2 analyses) and ash-sand mixture after leaching in the large column (average and standard deviation of 5 analyses)

\begin{tabular}{|c|c|c|c|}
\hline \multirow{2}{*}{$\begin{array}{l}\text { Analysis method } \\
\%\end{array}$} & \multicolumn{2}{|c|}{ XF/ICP-AES } & \multirow{2}{*}{$\begin{array}{c}\text { ICP-AES } \\
\text { Leached } \\
\text { (average \& stand. dev.) }\end{array}$} \\
\hline & Fresh 1 & Fresh 2 & \\
\hline $\mathrm{Al}_{2} \mathrm{O}_{3}$ & 11.5 & 10.7 & $10.8(0.46)$ \\
\hline $\mathrm{CaO}$ & 7.6 & 6.7 & $8.7(0.58)$ \\
\hline $\mathrm{Fe}_{2} \mathrm{O}_{3}$ total & 3.64 & 3.1 & $2.9(0.17)$ \\
\hline $\mathrm{K}_{2} \mathrm{O}$ & 3 & 3.1 & $2.8(0.08)$ \\
\hline $\mathrm{MgO}$ & 1.3 & 1.3 & $1.4(0.08)$ \\
\hline $\mathrm{MnO}$ & 0.07 & 0.07 & $0.1(0.00)$ \\
\hline $\mathrm{Na}_{2} \mathrm{O}$ & 1.7 & $\mathrm{~nm}$ & $\mathrm{~nm}$ \\
\hline $\mathrm{P}_{2} \mathrm{O}_{5}$ & 1.25 & 1.102 & $1.1(0.04)$ \\
\hline $\mathrm{SiO}_{2}$ & 67.4 & 70 & $60.4(0.7)$ \\
\hline $\mathrm{TiO}_{2}$ & 0.69 & 0.64 & $0.6(0.04)$ \\
\hline$S$ total & 0.26 & $\mathrm{~nm}$ & $0.22(0.07)$ \\
\hline $\mathrm{Cl}$ & 0.43 & $\mathrm{~nm}$ & $\mathrm{~nm}$ \\
\hline $\mathrm{LOI}\left(1000^{\circ} \mathrm{C}\right)$ & 1.4 & 2.16 & $3.0(0.29)$ \\
\hline Traces* & 0.56 & $\mathrm{~nm}$ & 0.6 \\
\hline Total ** & 100.8 & 101.8 & 94.3 \\
\hline $\mathrm{Al}^{\circ}(\%)$ & 1.40 & 1.45 & $0.6(0.05)$ \\
\hline \multicolumn{4}{|l|}{ Traces $\mathrm{mg} / \mathrm{kg}$} \\
\hline As & 46 & $\mathrm{~nm}$ & $27.5(2.12)$ \\
\hline $\mathrm{Ba}$ & 955 & $\mathrm{~nm}$ & $969.8(19.73)$ \\
\hline $\mathrm{Cd}$ & 4 & $\mathrm{~nm}$ & $3.4(0.89)$ \\
\hline Co & 61 & $\mathrm{~nm}$ & $59.2(15.99)$ \\
\hline $\mathrm{Cr}_{\text {total }}$ & 168 & $\mathrm{~nm}$ & $185.2(16.62)$ \\
\hline $\mathrm{Cu}$ & 1021 & $\mathrm{~nm}$ & $988.8(102.21)$ \\
\hline Mo & 8 & $\mathrm{~nm}$ & $<5$ \\
\hline $\mathrm{Ni}$ & 63 & $\mathrm{~nm}$ & $55.2(3.70)$ \\
\hline $\mathrm{Pb}$ & 473 & $\mathrm{~nm}$ & $473.2(23.19)$ \\
\hline $\mathrm{Sn}$ & 155 & $\mathrm{~nm}$ & $233.8(11.73)$ \\
\hline $\mathrm{Sr}$ & 235 & $\mathrm{~nm}$ & 187 (11.38) \\
\hline $\mathrm{Zn}$ & 2053 & $\mathrm{~nm}$ & $2268(183.05)$ \\
\hline
\end{tabular}

Notes: $\mathrm{nm}=$ non measured; $* 25$ traces analysed $* *$ total $=$ main elements + traces + LOI $\left(1000^{\circ} \mathrm{C}\right)$. 
Table 3

Batch leaching test at $\mathrm{L} / \mathrm{S}=10 \mathrm{l} / \mathrm{kg}$ : fresh ash-sand mixture and ash-sand mixture after leaching in the large column. All units in $\mathrm{mg} / \mathrm{kg}$ dry weight unless indicated otherwise.

\begin{tabular}{lccccc}
\hline \multicolumn{1}{c}{ Parameter } & $\begin{array}{c}\text { Fresh } \\
\text { ash-sand }\end{array}$ & $\begin{array}{c}\text { Leached } \\
\text { ash-sand }\end{array}$ & HW limit & $\begin{array}{c}\text { NHW } \\
\text { limit }\end{array}$ & IW limit \\
\hline $\mathrm{pH}(\mathrm{pH}$ units $)$ & 10.3 & 9.9 & & & \\
Conductivity $(\mu \mathrm{S} / \mathrm{cm})$ & 1580 & 661 & & & \\
Soluble fraction & 14307 & 6280 & 100000 & 60000 & 4000 \\
$\mathrm{Al}$ & 844 & 477.9 & & & \\
$\mathrm{Ca}$ & 2312 & 1389 & & & \\
$\mathrm{Mg}$ & $<5$ & $<10$ & & & \\
$\mathrm{Na}$ & 448 & 12 & & & \\
$\mathrm{~K}$ & 500 & 24 & & & \\
$\mathrm{Inorganic}$ Carbon & 718 & 82 & & & \\
$\mathrm{Cl}$ & 2697 & 16 & 25000 & 15000 & 800 \\
$\mathrm{SO}{ }_{4}$ & 1938 & 1760 & 50000 & 20000 & 1000 \\
$\mathrm{As}$ & $<0.1$ & $<0.1$ & 25 & 2 & 0.5 \\
$\mathrm{Ba}$ & 2.5 & 0.92 & 300 & 100 & 20 \\
$\mathrm{Cd}$ & $<0.02$ & $<0.02$ & 5 & 1 & 0.04 \\
$\mathrm{Cr}$ total & 0.27 & 0.84 & 70 & 10 & 0.5 \\
$\mathrm{Cu}$ & 0.03 & 0.07 & 100 & 50 & 2 \\
$\mathrm{Ni}$ & $<0.05$ & $<0.05$ & 40 & 10 & 0.4 \\
$\mathrm{~Pb}$ & $<0.02$ & 0.03 & 50 & 10 & 0.5 \\
$\mathrm{SiO}{ }_{2}$ & $<5$ & 13 & & & \\
$\mathrm{Sr}$ & 8.3 & 2.4 & & & \\
$\mathrm{Zn}$ & $<0.05$ & 0.1 & 200 & 50 & 4 \\
\hline
\end{tabular}

Notes: HW = Hazardous Waste, NHW = Non-Hazardous Waste, IW = Inert Waste. Limits from OJC (2002). 
Table 4

Synthesis of highest measured concentrations $\left(\mathrm{C}_{\max }\right)$ and corresponding values of $\mathrm{L} / \mathrm{S}(1 / \mathrm{kg})$

\begin{tabular}{lcccccccc}
\hline \multicolumn{1}{c}{ Element } & \multicolumn{2}{c}{ Large Column } & \multicolumn{2}{c}{ Outdoor Cell } & \multicolumn{2}{c}{ Indoor Cell } & \multicolumn{2}{c}{ Laboratory Column } \\
\hline & $\mathrm{C}_{\max }$ & $\mathrm{L} / \mathrm{S}$ & $\mathrm{C}_{\max }$ & $\mathrm{L} / \mathrm{S}$ & $\mathrm{C}_{\max }$ & $\mathrm{L} / \mathrm{S}$ & $\mathrm{C}_{\max }$ & $\mathrm{L} / \mathrm{S}$ \\
$\mathrm{Cl}(\mathrm{mg} / \mathrm{l})$ & 96100 & 0.008 & 28493 & 0.022 & 27600 & 0.032 & 6612 & 0.1 \\
$\mathrm{Na}(\mathrm{mg} / \mathrm{l})$ & 32100 & 0.008 & 8660 & 0.022 & 5285 & 0.032 & 1172 & 0.1 \\
$\mathrm{~K}(\mathrm{mg} / \mathrm{l})$ & 25000 & 0.008 & 8401 & 0.022 & 5045 & 0.032 & 1049 & 0.1 \\
$\mathrm{Ca}(\mathrm{mg} / \mathrm{l})$ & 30000 & 0.008 & 11969 & 0.022 & 8020 & 0.032 & 2385 & 0.1 \\
$\mathrm{SO}_{4}(\mathrm{mg} / \mathrm{l})$ & 306 & 0.008 & 42 & 0.2 & 170 & 0.032 & 95 & 5 \\
$\mathrm{Al}(\mathrm{mg} / \mathrm{l})$ & 146 & 0.67 & 98 & 0.29 & 119 & 0.51 & 138 & 2 \\
$\mathrm{Cr}(\mu \mathrm{g} / \mathrm{l})$ & $41 *$ & 3.02 & 9 & 0.26 & $122 *$ & 2.43 & 32 & 20 \\
\hline
\end{tabular}

*: increasing at the end of the experiment 

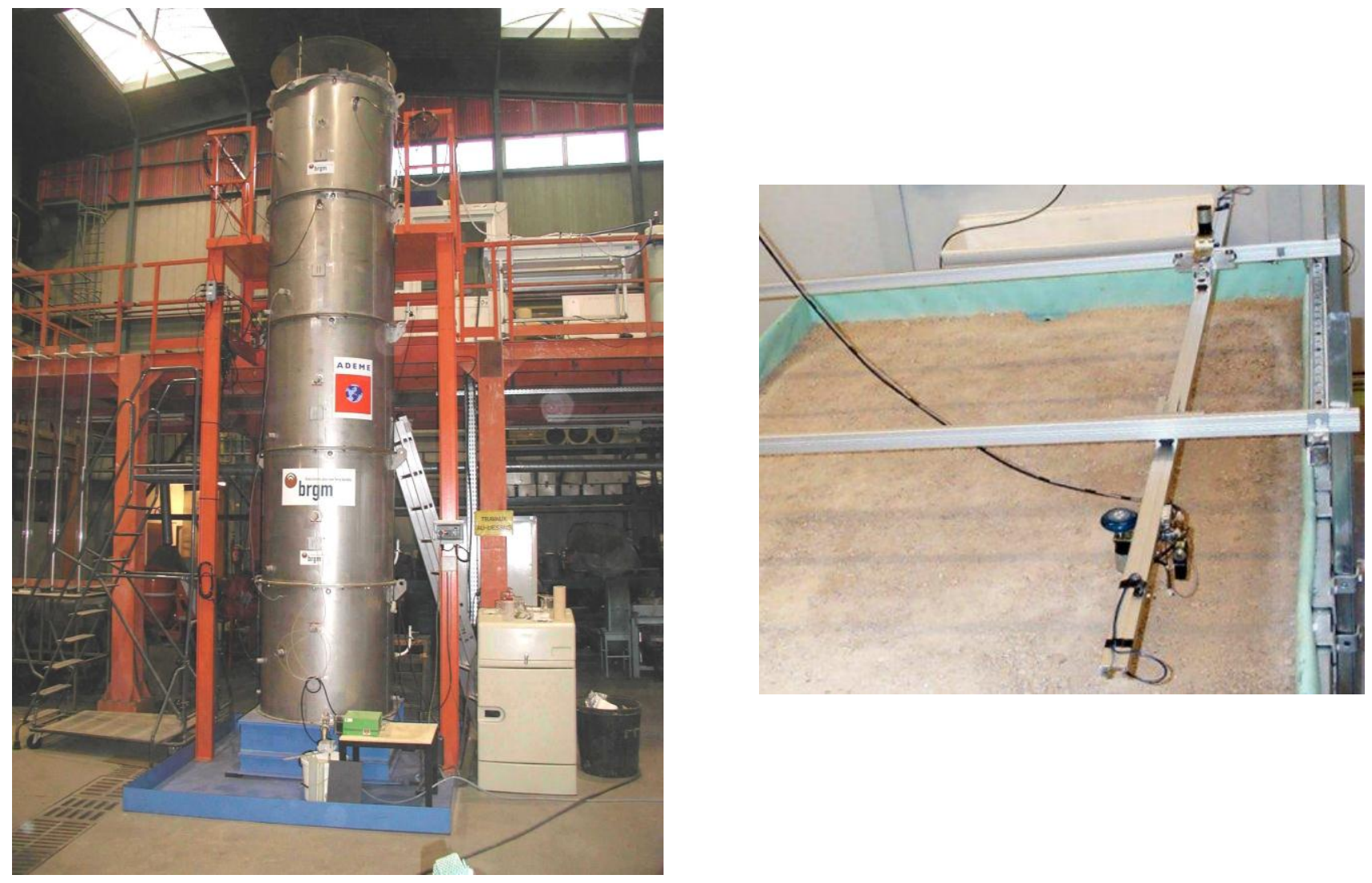

Fig. 1.

View of the large column (left) and automatic spraying system of the indoor lysimeter cell (right) 


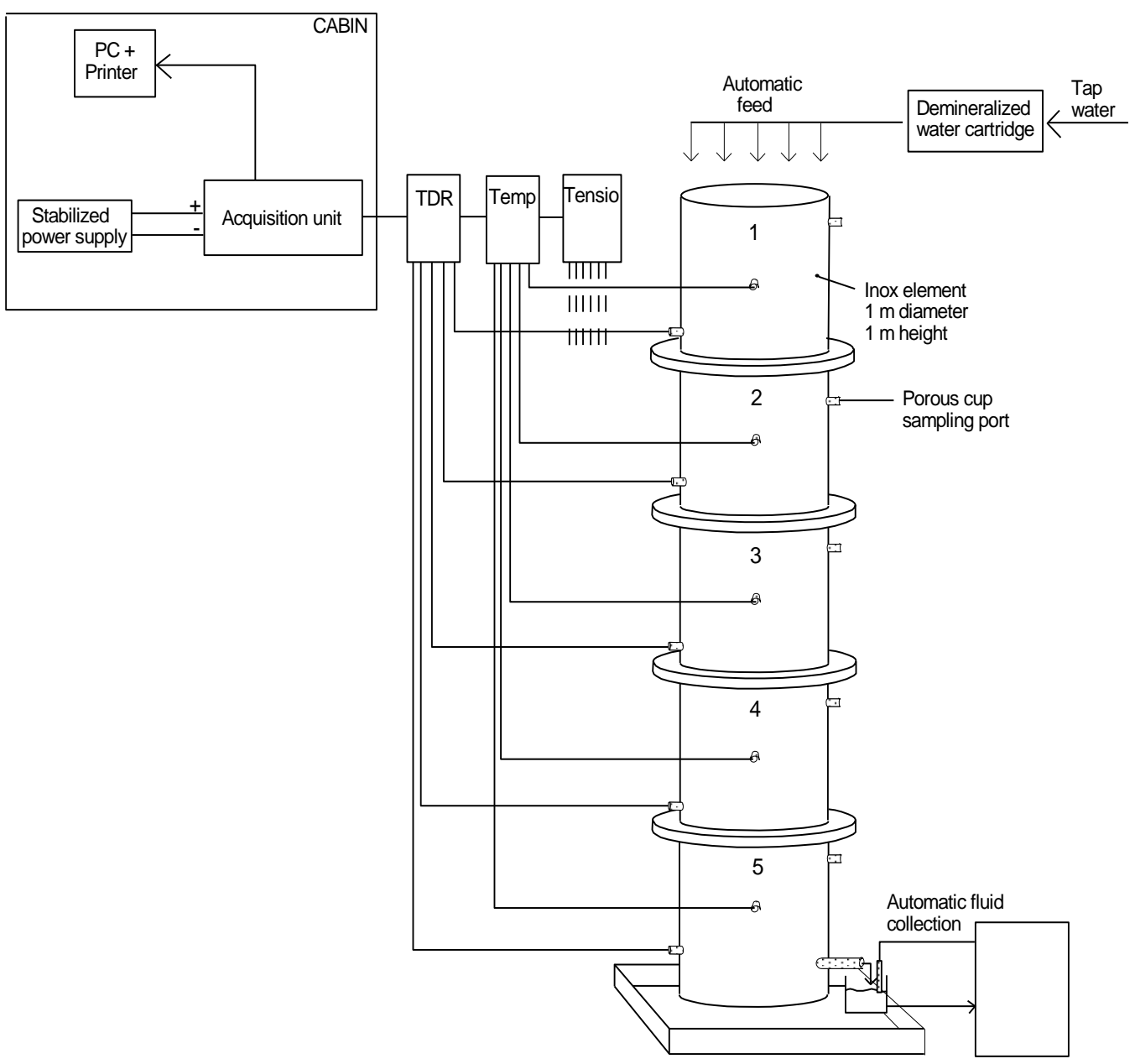

Alternative Fig. 1.

Schematic of the large column experimental setup 

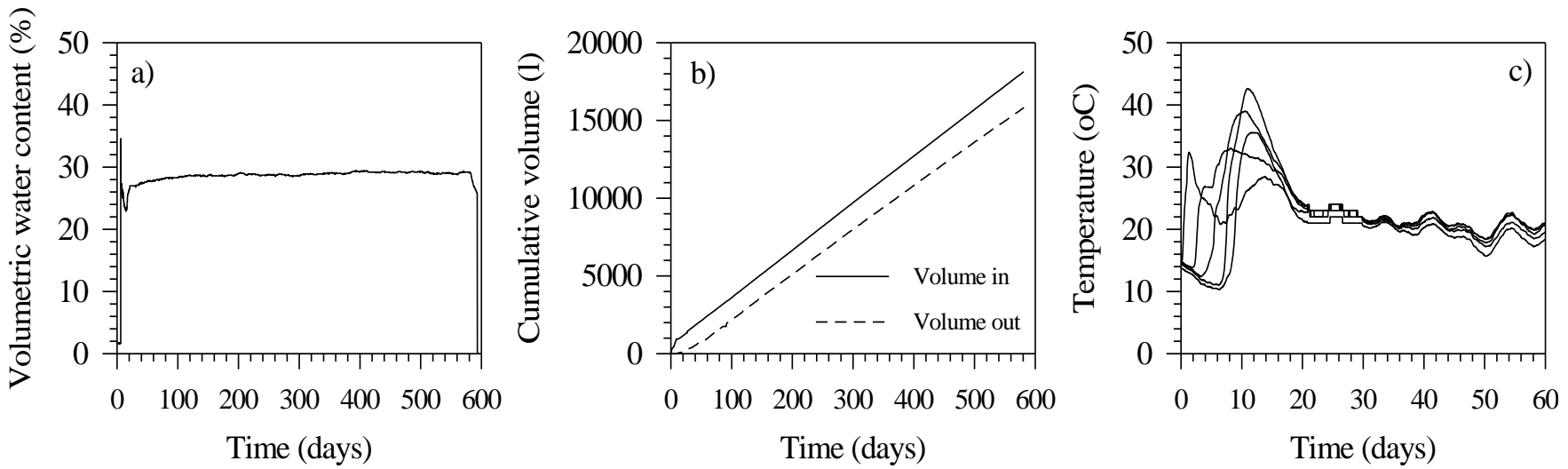

Fig. 2.

Data from the large column: (a) volumetric water content at depth $294 \mathrm{~cm}$, (b) cumulative volumes in and out of the column and (c) temperature variations measured at several depths $(0.8,1.8,2.5,3.5,4.4 \mathrm{~m})$.
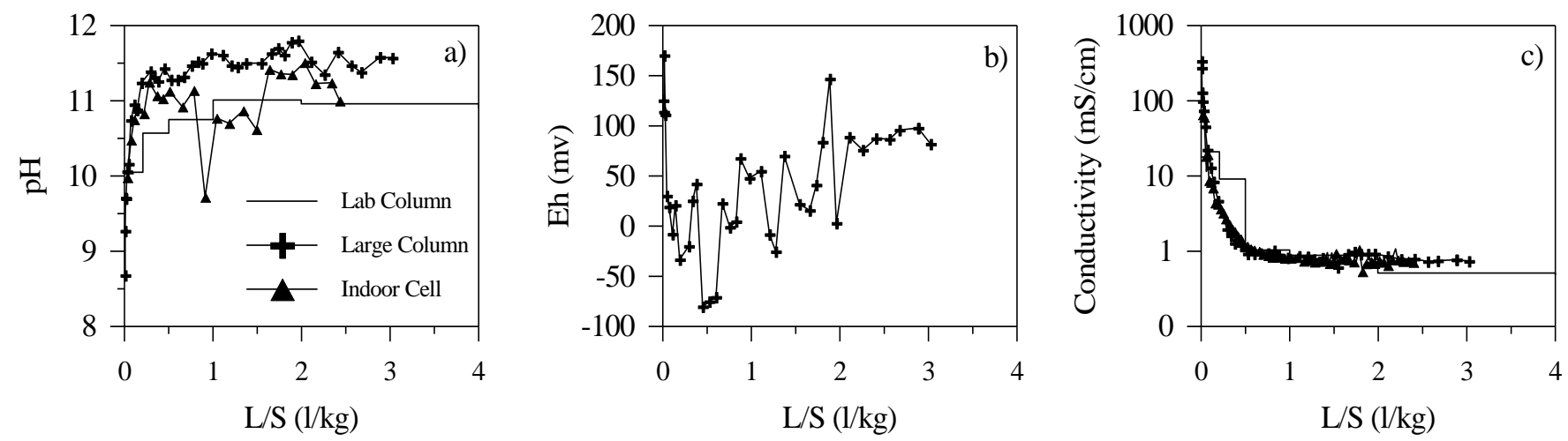

Fig. 3.

Results from dynamic flow experiments as a function of $\mathrm{L} / \mathrm{S}$ ratio: $\mathrm{pH}$, Eh and electrical conductivity. 

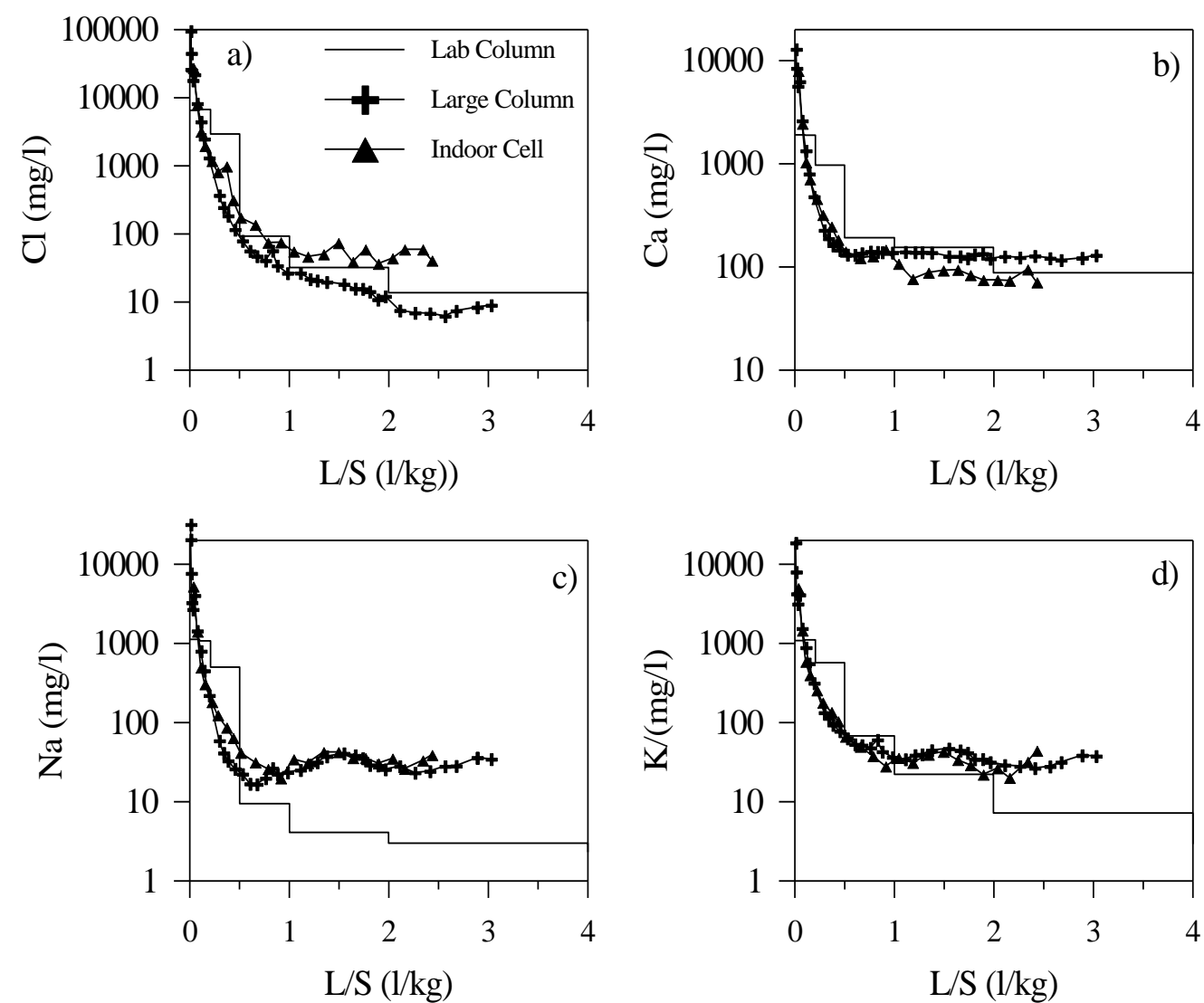

Fig. 4.

Results from dynamic flow experiments as a function of L/S ratio: non-reactive constituents.
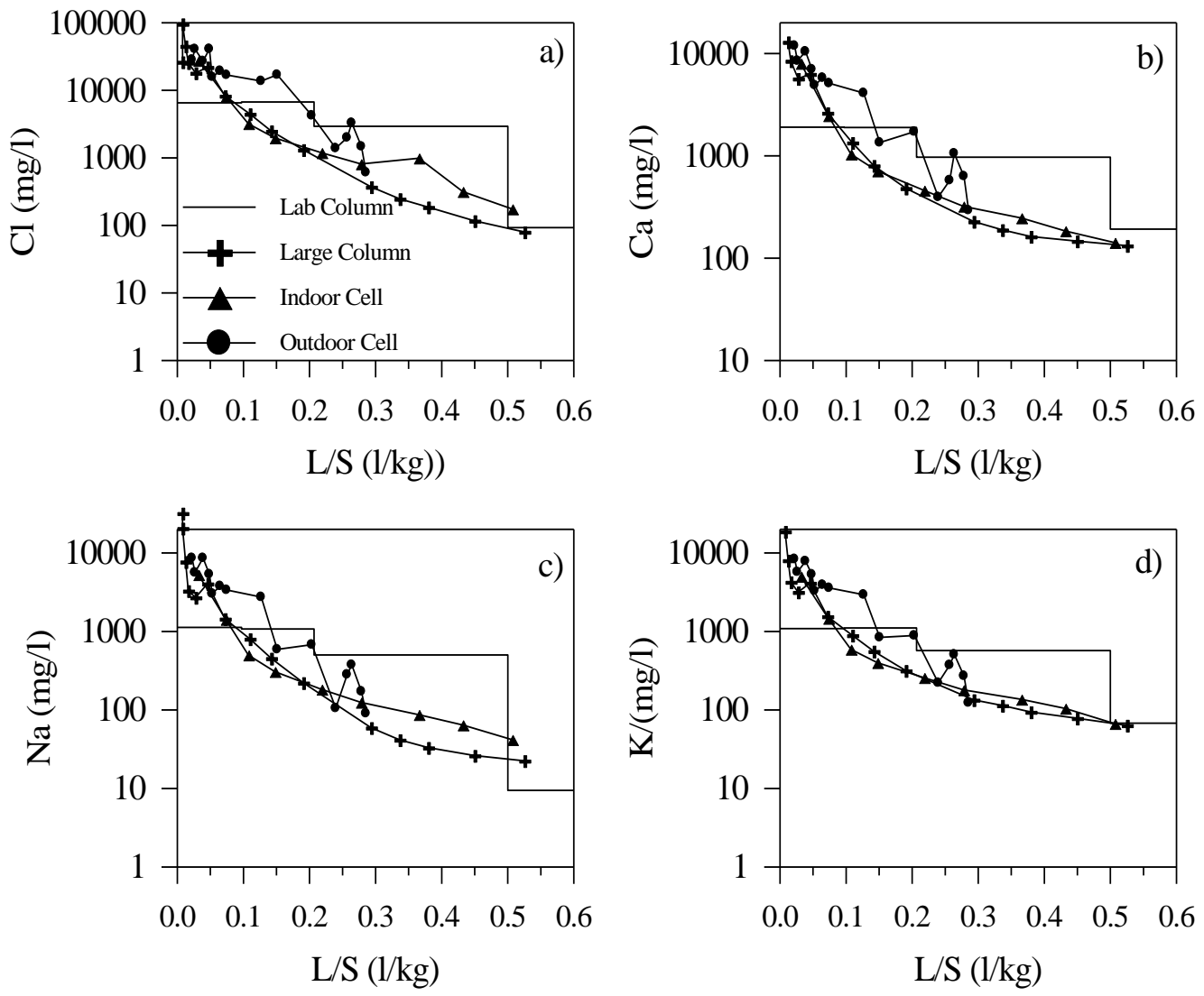
Fig. 5.

Results from dynamic flow experiments, including the outdoor cell lysimeter, as a function of L/S ratio: non-reactive constituents.
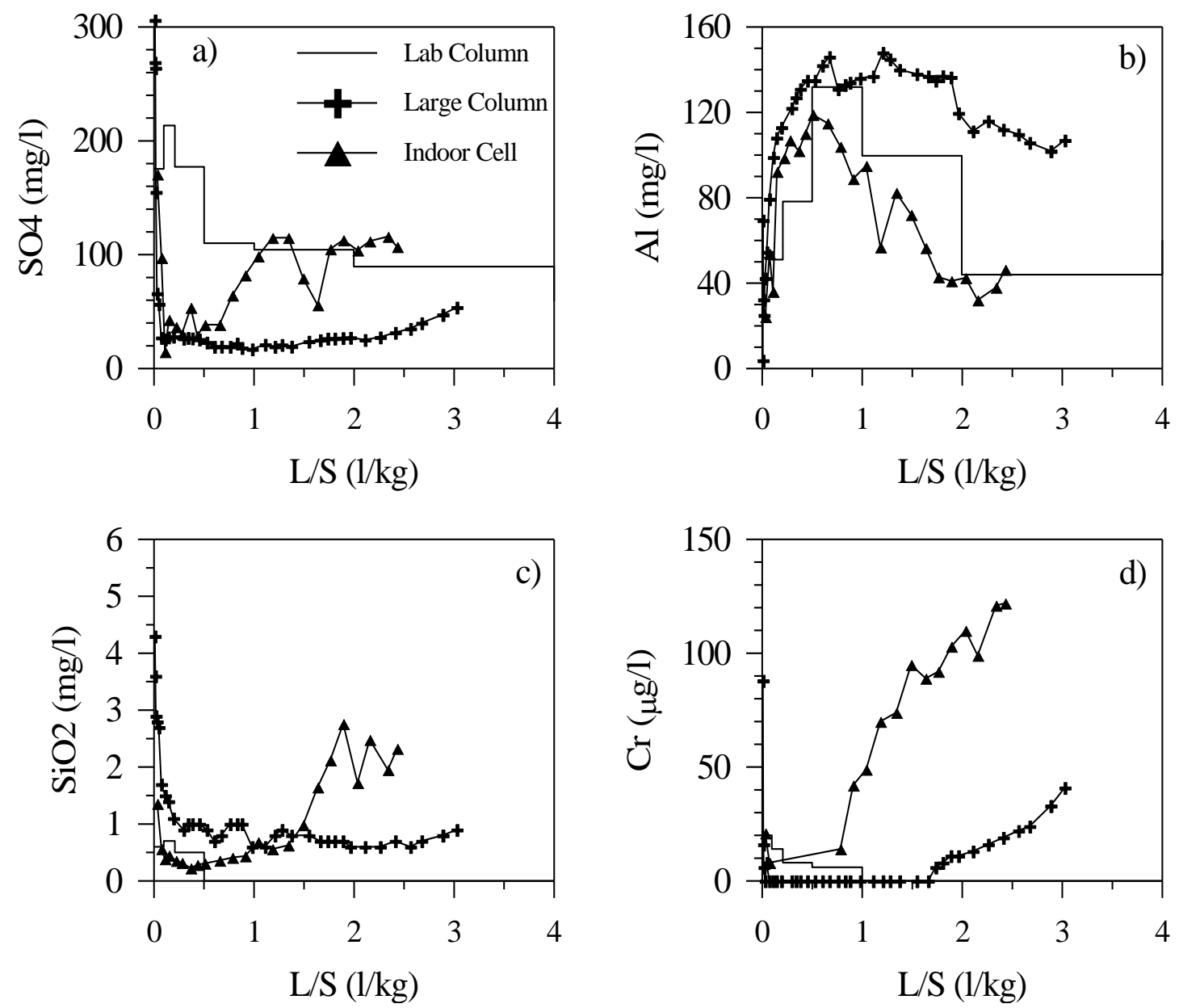

Fig. 6.

Results from dynamic flow experiments as a function of L/S ratio: reactive constituents.
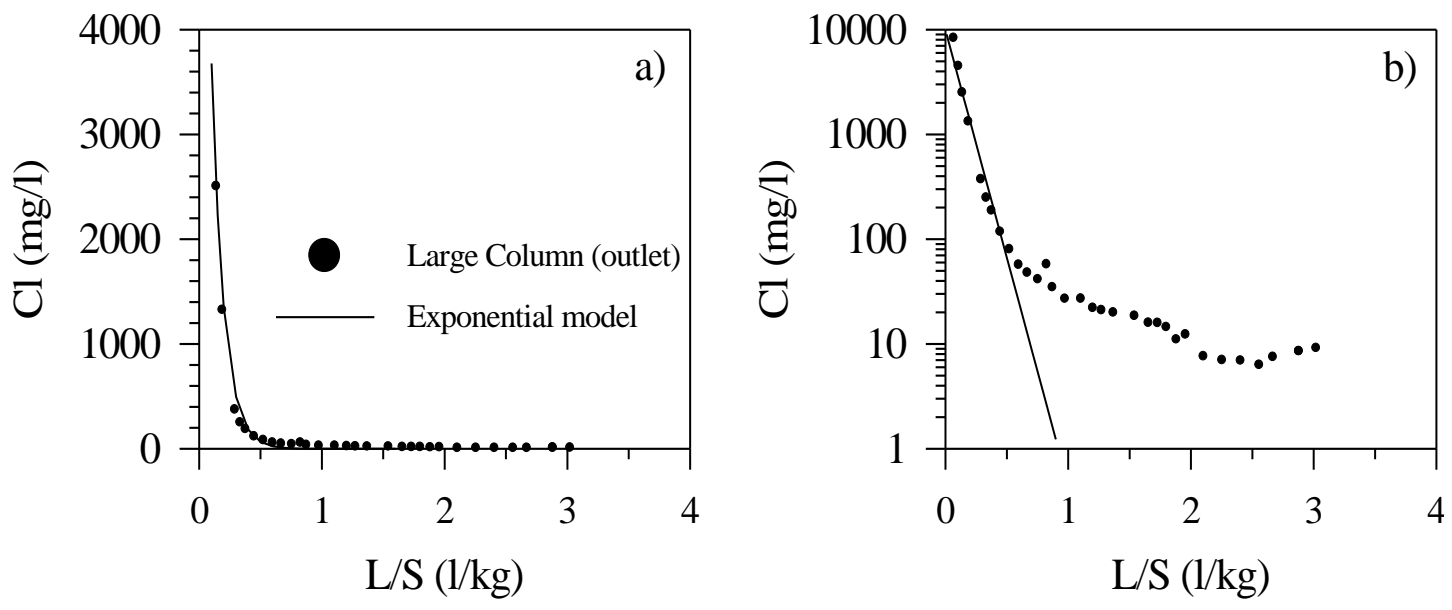
Fig. 7.

Attempt to reproduce chloride concentrations measured at the outlet of the large column using an exponential decay model
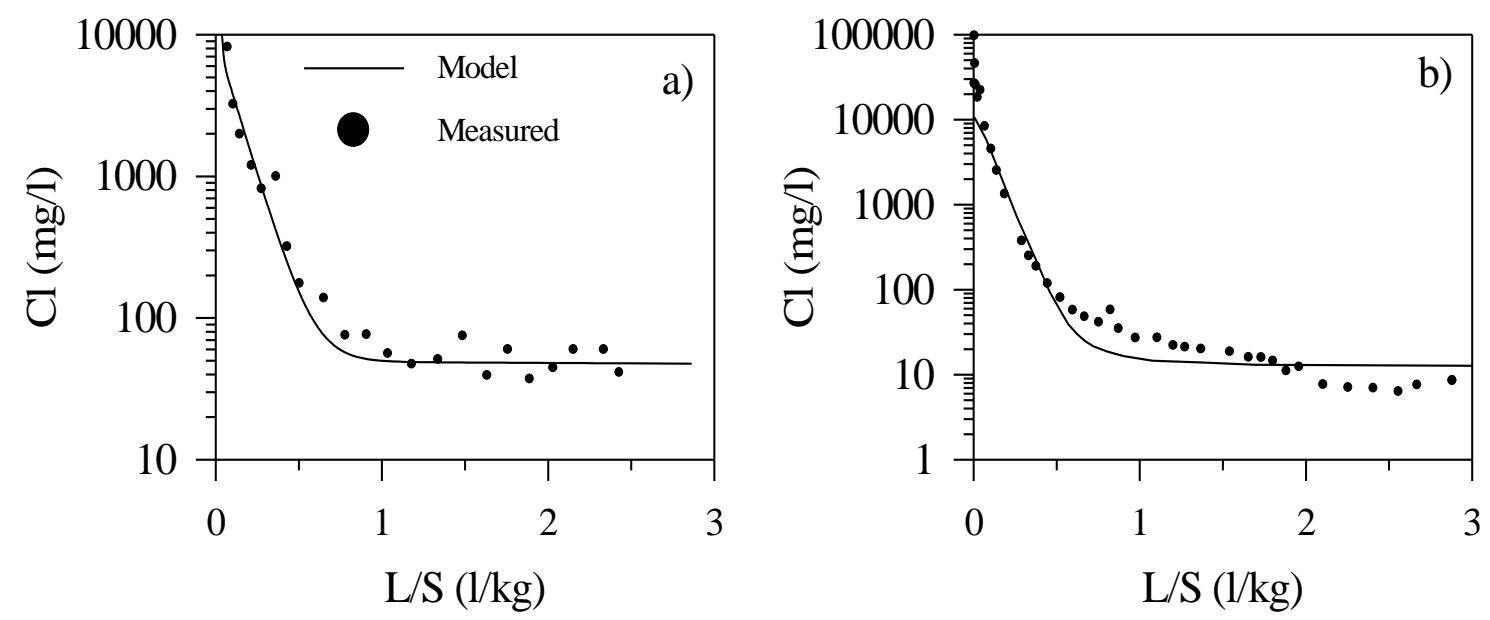

Fig. 8.

CSTR cascade model simulation of chloride measured at the outlet of the indoor lysimeter cell (a) and of the large column (b)
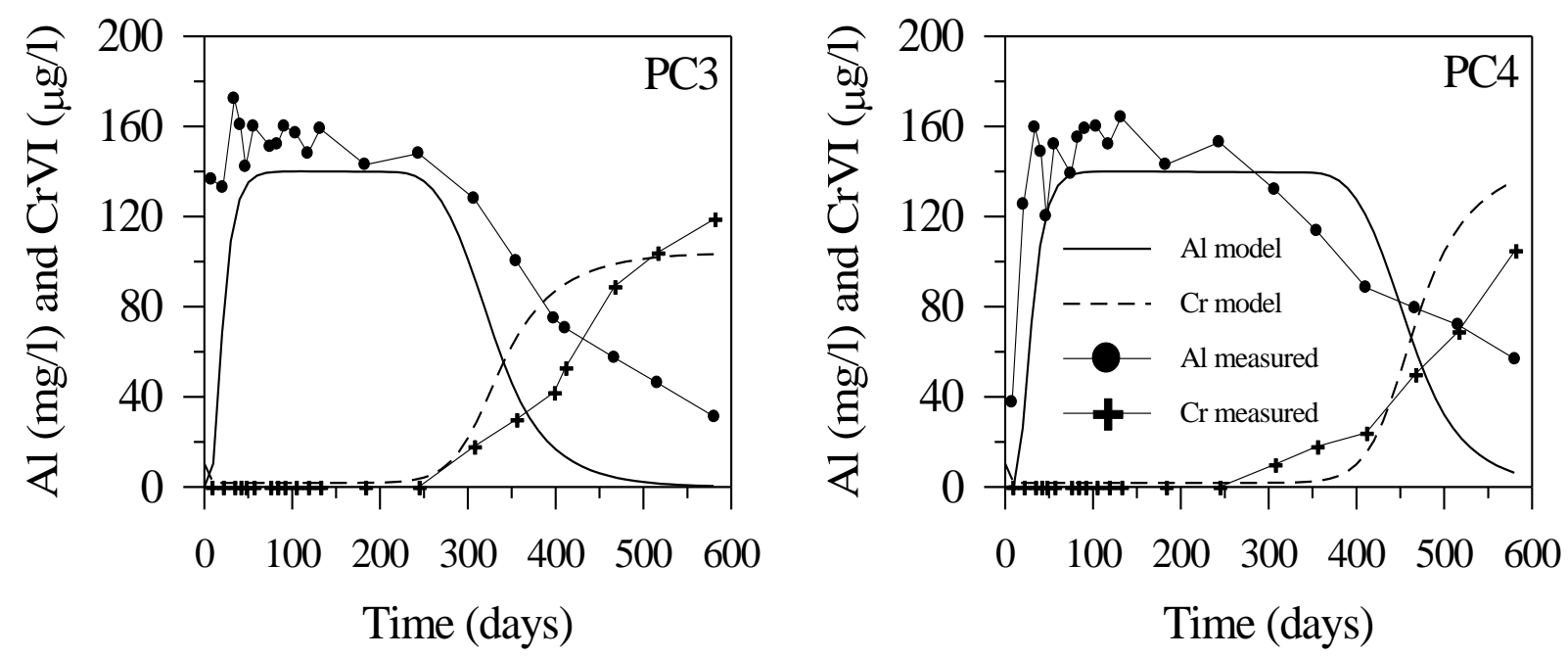

Fig. 9.

Comparison between measured and simulated concentrations of $\mathrm{Al}$ and $\mathrm{Cr}(\mathrm{VI})$ at two depths within the large column (PC3: $254 \mathrm{~cm}$ and PC4: $356 \mathrm{~cm}$ ) 


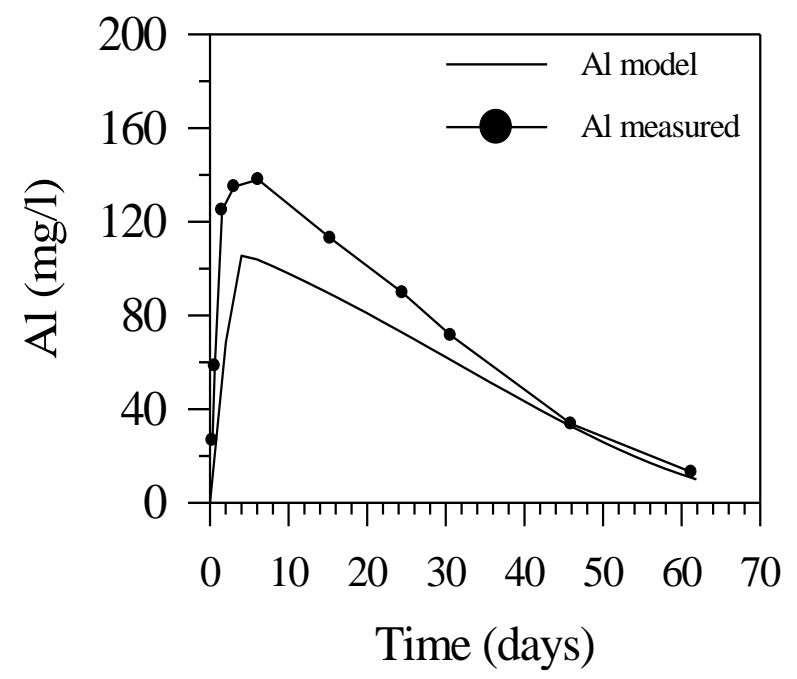

Fig. 10.

Comparison between measured and simulated values of $\mathrm{Al}$ at the outlet of a laboratory column using the same fitting parameters as for Fig. 9

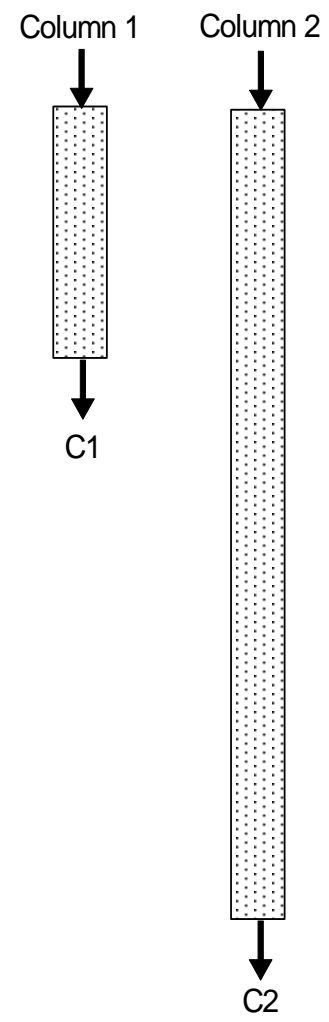

a)

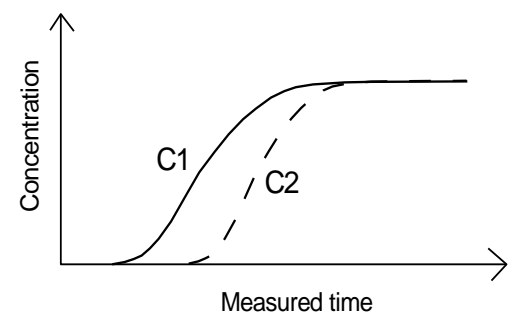

b)

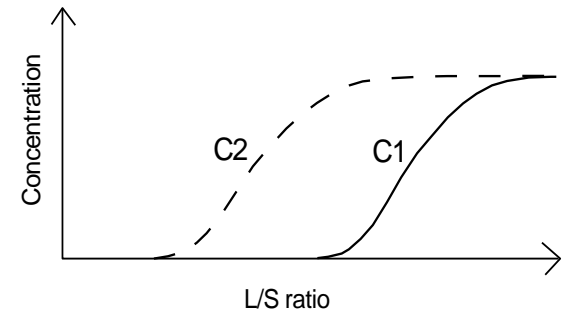

c)

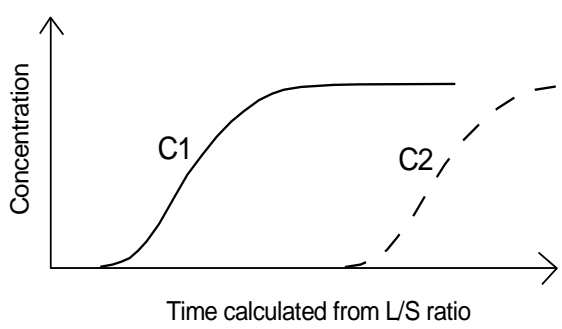

Note : the dashed curve is offset to the right with respect to a)

Fig. 11.

Illustration of the error involved in using the L/S ratio for up-scaling in the case of a kinetic control on soluble constituent release 